\title{
Effects of long-term proBNP cardiac gene delivery in experimental hypertensive heart disease
}

\author{
Alessandro Cataliotti*, Jason M Tonne, Guido Boerrigter, Salvatore Mangiafico, John C Burnett, Yasuhiro Ikeda \\ From 5th International Conference on cGMP: Generators, Effectors and Therapeutic Implications \\ Halle, Germany. 24-26 June 2011
}

\section{Background}

In the current study, we tested the effects of sustained cardiac proBNP gene delivery on blood pressure (BP), cardiac function and remodeling in spontaneously hypertensive rats (SHR).

\section{Methods}

We used the myocardium-tropic adeno-associated virus serotype 9 (AAV9) vector to achieve continuously enhanced cardiac rat proBNP expression. " $\mathrm{p}<0.05$ vs treated rats.

\section{Results}

In SHR, a single systemic administration of AAV9 vector allowed longterm, cardiac BNP overexpression with an increase in plasma BNP levels as compared with untreated SHR $\left(433.3 \pm 17\right.$ vs $\left.60.6 \pm 15^{*} \mathrm{pg} / \mathrm{ml}\right)$. This further resulted in reductions in systolic $(121 \pm 11$ vs 184 $\pm 13^{*} \mathrm{~mm} \mathrm{Hg}$ ) and diastolic (103 \pm 5 vs $148 \pm 24^{*} \mathrm{~mm} \mathrm{Hg}$ ) BP for nine months after injection as compared with untreated SHR. Left ventricular (LV) thickness $(1.87 \pm 0.1$ vs $\left.2.16 \pm 0.3^{*} \mathrm{~mm}\right), \mathrm{LV}$ end-systolic dimensions $(3.96 \pm 0.3$ vs $\left.4.66 \pm 0.6^{*} \mathrm{~mm}\right)$ and $L V$ mass $\left(0.4 \pm 0.01\right.$ vs $0.49 \pm 0.01^{*}$ gr) were reduced, while ejection fraction was increased ( $83 \pm 2$ vs $74 \pm 4^{*} \%$ ) in BNP-treated compared to untreated SHR. Circumferential systolic strain $(-5.04 \pm 0.4$ vs -3.74 $\left.\pm 0.4^{*} \%\right)$ and strain rate of the early phase of diastole $(-4.57 \pm 2.1$ vs $-2.41 \pm 1.31 / \mathrm{s})$ were improved in BNP-treated compared with controls. Importantly, the improvement in cardiac function and structure also resulted in a significant increase in survival $(\mathrm{p}<0.001$ vs untreated SHR). Non-cardiac overexpression of BNP, via AAV2 vector, was not associated with changes in plasma BNP

\footnotetext{
* Correspondence: cataliotti.alessandro@mayo.edu

Mayo Clinic, Cardiorenal Research Laboratory, 200 First St SW, Rochester, MN 55905, USA
}

and BP in SHR. Nevertheless, normotensive Wistar rats injected with AAV9 proBNP vector showed significantly reduced heart/body weights $(0.31 \pm 0.1$ vs $3.9 \pm 0.1 * \%)$ four weeks after injection without $\mathrm{BP}$ reduction compared to untreated rats.

\section{Conclusion}

AAV9 vector facilitates sustained cardiac proBNP overexpression improves both systolic and diastolic cardiac function in hypertensive heart disease. Long-term proBNP delivery improved survival in SHR. The effects on cardiac structure and function occurred independently of BP lowering effects in normotensive Wistar rats.

Published: 1 August 2011

\section{doi:10.1186/1471-2210-11-S1-016}

Cite this article as: Cataliotti et al:: Effects of long-term proBNP cardiac gene delivery in experimental hypertensive heart disease. $B M C$ Pharmacology 2011 11(Suppl 1):016.

Submit your next manuscript to BioMed Central and take full advantage of:

- Convenient online submission

- Thorough peer review

- No space constraints or color figure charges

- Immediate publication on acceptance

- Inclusion in PubMed, CAS, Scopus and Google Scholar

- Research which is freely available for redistribution

\section{Biomed Central}

